Portland State University

PDXScholar

1975

\title{
The Ethnohistory of Baker Cabin, a Clackamas County Pioneer Site
}

\author{
V. Claire Woodward \\ Portland State University
}

Follow this and additional works at: https://pdxscholar.library.pdx.edu/open_access_etds

Part of the Archaeological Anthropology Commons, and the Social and Cultural Anthropology Commons

Let us know how access to this document benefits you.

\section{Recommended Citation}

Woodward, V. Claire, "The Ethnohistory of Baker Cabin, a Clackamas County Pioneer Site" (1975). Dissertations and Theses. Paper 2523.

https://doi.org/10.15760/etd.2524

This Thesis is brought to you for free and open access. It has been accepted for inclusion in Dissertations and Theses by an authorized administrator of PDXScholar. Please contact us if we can make this document more accessible: pdxscholar@pdx.edu. 
AN ABSTRACT OF THE THESIS OF V. Claire Wootwand for the Masters of Arts in Antrropology presented May 13, 1975.

Title: The Ethnohistory of Baker Cabin, A Clackamas County Pioneer Site. APPROVED BY MEMBERS OF THE THESIS COMMTTIEE:
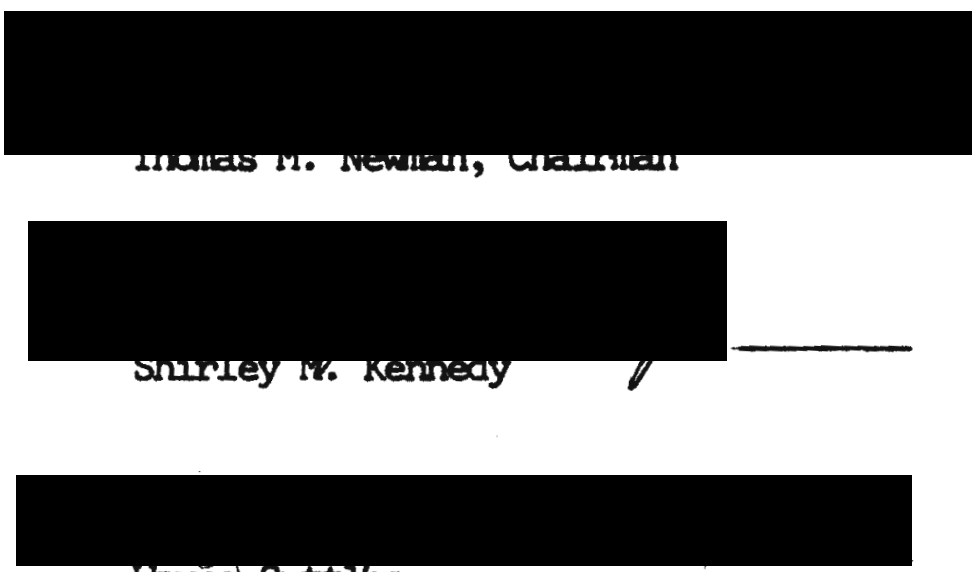

Wayre-suttles

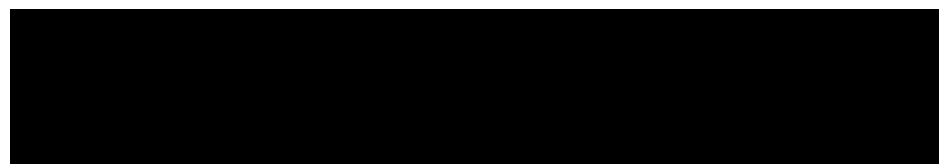

Victor C. Dant

Baker Cabin, a pioneer log structure, is located on privately owmed property near the community of Carver, Oregon. According to traditional accounts the cabin has existed continuously on this site since its constmuction in 1856. Archeological excavations of the cabin's foundation and the surrounding area uncovered dateable artifacts and a second foundation with an associated well. Analysis of the artifacts associated with the present cabin foundation indicate a post-1870 construction date while those associated with the second foundation and its 
well indicate an $1850^{\prime} \mathrm{s}$ cocupation.

Four hypotheses that are explored in this paper can be derived from the interpretation of all available data:

1. Baker Cabin was constructed in 1856 at a presently undiscovered site on the claim but was moved to its present location about 1870.

2. Baken Cabin was constructed in 1856 on the precise spot that it now stands but reconstruction by the 01d Timers' Association involved a complete rebuilding of the foundation.

3. Baker Cabin was constructed in 1856 on the present foundation but extensive repairs were done on the foundation in the 1870's. The old foundation represents a smaller cabin occupied from the late 1840's until 1856.

4. The old foundation with its associated well represents the original construction and habitation of the site. The present cabin is not the original 1856 cabin referred to in tradition but is rather a cabin canstructed about 1870.

Data used in this research include excavated materials, informant interviews, and historical documents. The excavated materials consist of glass and pottery sherds, buttons, cartridges, and toys. Informants interviewed are Baker descendants, and they provided recollections, documents, and pictures. Historical documents used include census and tax assessment reconds, newspapers, Donation Land Claim material, and family ledgers.

Results of this research reveal that the authentic history of Baker Cabin will not be known unless further evidence becanes available. The first two hypotheses would seem to have no validity, however, the third 
and fourth hypotheses can be supported by the available data. 
THE EIFNOHISTORY OF BAKER CABTN,

A CLACKAMAS COUNTY PIONEER STIE

\author{
by \\ V. Claire Woodwand
}

A thesis submitted in partial fulfillment of the requirements for the degree of

\author{
MASTER OF ARIS \\ in \\ ANTHROPOLOGY
}

Portland State University

1975 
TO THE OFFICE OF GRADUATE STUDIES AND RESEARCH:

The menbers of the committee approve the thesis of

v. Claire Woodward presented May 13, 1975.

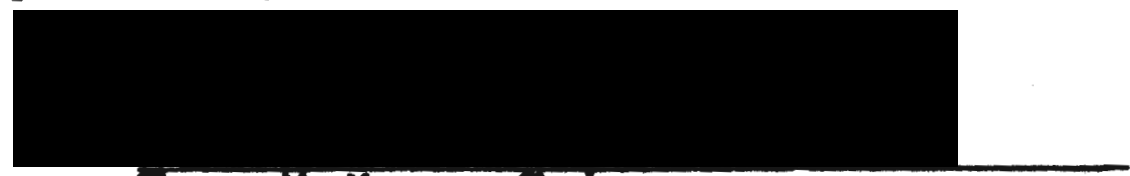

Thomas M. Newman, Chairman
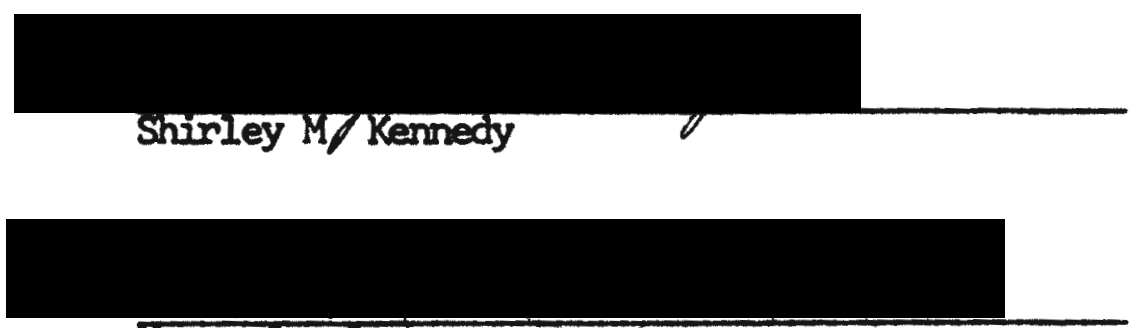

hayse suttlest

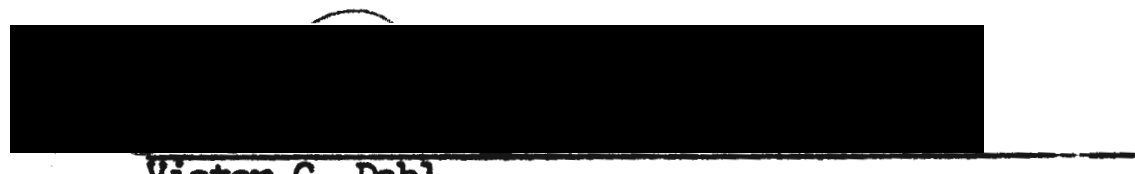

Victor C. Dahl

APPROVED:

Shinley MJ Kennedy, Head, Eepartment of Antrropology

David 1. Clark, Dean of Gractuate Studies and Research 


\section{ACANOWLEDEMENTS}

I wish to express my gnatitude to Dr. John A. Woodwand who directed the excavations of the Baker Cabin site and kindly placed the recovered artifacts at my disposal. Dr. Woodwand also spent many hours discussing this project with me and encouraged my research.

My special thanks go to Diane DeBlasio, Linda Sands, Yvonne Hajda, Peggy Norman, and other close friends whose faith in me made this thesis possible.

During the course of my research I met and talked with many members of the Hattan and Mumpower families. Fach one gave willingly of his or her time and recollections and to each I owe a debt of gratitude. 
TABLE OF CONTENTS

PAGE

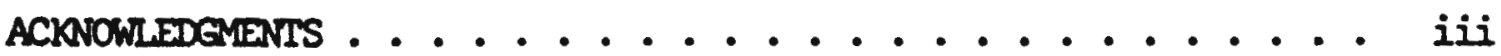

LIST OF TABLES .................. v v

LIST OF FIGURES ........................ vi

CHAPTER

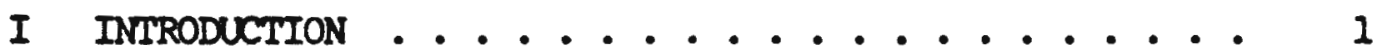

The site ................. 2

II HISTORY OF THE CABIN AND ITS OCCUPANTS ....... 4

The Hattans .............. 6

The Bakens ............... 9

The Mumpowers .............. 11

III ARCHITECTURAL HISTORY OF THE CABIN ......... 14

IV ARTIFACT DESCRIPTION AND DATING .......... 27

Glass................... 28

Pottery .................. 33

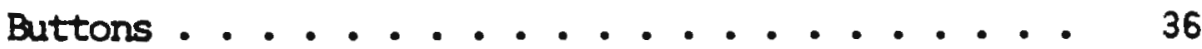

Cartridges ............... 40

Toys ..................... 42

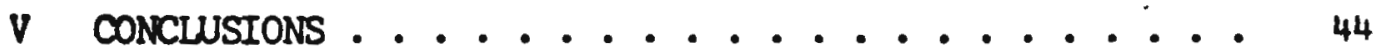

Bibliography ............ . . 49

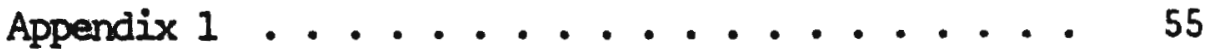
Map

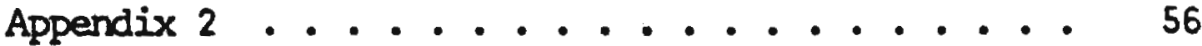

J. G. Munmower's Statement

Appendix 3 ....................... 58 Glossary 


\section{LIST OF TABLES}

\section{TABLE}

PAGE

I Provenience of Buttons .............. 40 


\section{LIST OF FIGURES}

FIGURE

PAGE

1 Families associated with Baker Cabin . . . . . . 7

2 Baker Cabin circa 1914 . . . . . . . . . . . 17

3 Abandoned well after excavation .......... 21

4 Relative location of use sites of Baker Cabin

locality $1900 \ldots . . . . . . . . . . . . .22$

5 John, Clayton, and Elton Hatton near the chickenhouse at Baker Cabin cinca 1900 . . . . 23

6 Baker Cabin circa 1900 showing the attached structure on the west end .......... 24

7 Baker Cabin circa 1890 showing the attached structure on the west end .......... 25

8 "L \& W 5" sherd in situ between foundation stones of Baker Cabin . . . . . . . . . 46 


\section{CHAPTER I}

\section{INTRODUCTION}

There are three sources of information available to the anthropologist about historic sites: the site itself, historic reconds, and people who lived on those sites (Adams 1974). The purpose of this paper is to use these sources in regard to the dating of the construction and reconstruction of the occupations of Baker Cabin; a 19th century Elro-American habitation site. This report will also contribute additional information regarding the life styles of the American pioneens who traveled west and settled the Oregon Territory. Sources that I will use in this endeavor include: (1) interviews with informants who actually occupied the cabin or have knowledge of the cabin; (2) written accounts including census materials, tax assessment records, newspapers, and family ledgers; (3) archeological materials. The last will include an account by Wahlke and Woodward (1974) and other previously unreported Euro-American archeological material that I will describe and date.

The original intent of my research was to test the currently accepted cabin construction date against the dateable archeological materials and the other sources to discern how well they converged or agreed. After careful analysis, however, of all sounces I find that the problem is not simply one of convergence or divergence of data. Rather there are four hypotheses that will be explored in this paper which can be derived from the interpretation of all available evidence. These 
are:

1. Baker Cabin was constructed in 1856 at a presently undiscovered site on the claim but was moved to its present location about 1870 .

2. Baker Cabin was constructed in 1856 on the precise spot that it now stands but reconstruction by the old Timers' Association involved a complete rebuilding of the foundation.

3. Baker Cabin was constructed in 1856 on the present foundation but extensive repairs were done on the foundation in the $1870^{\prime} \mathrm{s}$. The old foundation represents a smaller cabin occupied from the late 1840's until 1856.

4. The old foundation with its associated well represents the original construction and habitation of the site. The present cabin is not the oxiginal 1856 cabin referred to in tradition but is rather a cabin constructed about 1870.

\section{The Site}

Baker Cabin is a pioneer log cabin located in the vicinity of the town of Carver in Clackamas County, Oregon. The site includes the cabin, an excavated foundation, and several structures constructed after 1940. It is situated in the southwest quarter of Section 18, Township 2 South, Range 3 East, and is located about 90 feet above and 500 feet south of the Clackamas River (Appendix 1).

The cabin and adjoining structures are maintained as an historic site by the Old Timers' Association of Oregon and are open to the public. Test excavations of the site were conducted by archeology field classes 
from Mount Hood Community College during the summers of 1973 and 1974. 
CHAPTER II

\section{HISTORY OF THE CABIN AND ITS OCCUPANTS}

The history of Baken Cabin is closely linked to three families related by intermarriage, the Bakers, the Hattans, and the Mumpowers. There are a great number of Hattan and Mumpower descendants presently Iiving in Clackamas County, however, Baker descendants are unkown. Figure 1 shows those members most closely connected to the cabin and indicates individuals who served as informants.

Although each of my informants provided invaluable information, one, Marian Mumpower Charriere, allowed me access to her own twenty years of research into family history. Marian Charriere, the daughter of Milo Mumpower and the niece of Mary Elizabeth Mumpower Hattan, is 45 years old and has been gathering documents and information since the mid 1950's. She has in her possession the xerox copies of many documents she obtained through the years from various U.S. Govermment agencies. These include legal petitions by Jane Baker and L. L. Baker, Carlin Baxter's Civil War service record, sworn affidavits concerning land claims, and a U.S. Goverment document denying Horace Baker's land claim. Mrs. Charriere spent many years collecting these copies but unfortunately kept no record of where they actually originated. She was very close to Mary Elizabeth Mumpower Hattan who was also very interested in family history and had lived in Baker Cabin. This close relationship gave Mrs. Charriere the impetus for her research. 
Elton Hattan and Bessie Hattan Weaven are the son and daughter of Mary Elizabeth Mumpower Hattan and were also very helpful as informants. I had the good fortune to first interview Elton at the Hattan Clan's annual picnic which was held at Baker Cabin in August 1974. Eltan walked over the entire site with me and provided a verbal picture of the area as it looked in 1900 when he lived there. At a second interview he provided a picture of his brother, his father and himself standing in front of the chickenhouse at Baker Cabin site. Bessie Hattan Weaver was interviewed on three different occasions, twice at her home in Milwaukie and once at the Hattan's annual picnic. She made available several documents including a speech written and presented by Mary Elizabeth Mumpower Hattan at Pioneer Days in Oregon City in 1944.

Isabel Hattan MacFarlane, the granddaughter of Mark Hattan, is 79 years old and resides on a portion of the original Hattan land claim near Carver. She was interviewed at her home and later at the Hattan picnic. She provided a family ledger written by Clara Dart, a daughter of Mark Hattan, as well as her own recollections of family history.

Verryl Mumpower, great grandson of Jane Baker and uncle of Marian Charriere, is in his sixties and lives in Carver. Although most willing to help he is essentially uninterested in family history and could provide few helpful recollections. He does, however, have Julia Baxter Mumower's Bible which contains the Mumpower family geneology which proved very useful.

The Oregon Historical Society Library also provided much material concerning the history of Baker Cabin and its various occupants. The microfilm collection supplied the U.S. Census for 1850-1880, the Clacka- 
mas County Census for 1849 and 1856, the Clackamas County Tax Assessment Rolls for 1856-1859, Oregon Donation Land Clain records, and Oregon City newspapers from 1848 to the present. The following history of Baker Cabin represents a synthesis of both documents and informant recollections.

\section{THE HATTANS}

The family most closely and continuously associated with the cabin is that of the Hattans whose origin is in Vinginia. Jane Hattan was born in Rockbridge County, Vinginia, in 1820 and her brother Mark was born the following year. There were nine children in the family and the family moved from Vinginia to Ohio in 1830 and then on to Marshall County, Illinois, in 1836 (Damt n.d.). In 1838 Jane Hattan married Morris Baxter at her parents' home in Marshall County. The Baxters had three children: Carlin, born January 3, 1839; Julia Ann, born January 11, 1840; and Mary Lucinda, born April 3, 1843. Soon after the birth of their thind child Morris Baxter disappeared carrying a lange sum of money. Because of this mysterious and unexpected disappearance it was assumed that he was mundered by bandits (Anonymous n.d.).

Mark Hattan married Martha Patterson on April 16, 1845, (Dart n.d.) and in this same year, according to swom affidavits, Jane met Honace Baker and they agreed to live together as husband and wife Marian Charriere personal communication). Horace Baker's previous history is unknown except that he lists his birthplace as Vermont (U.S. Goverrment 1850-1880) and documents dating from 1882 indicate that prior to 1845 he fathered four children (Marian Charriere personal communication). On May 7, 1846, Mark and Martha Hattan, Jane Hattan and Horace 


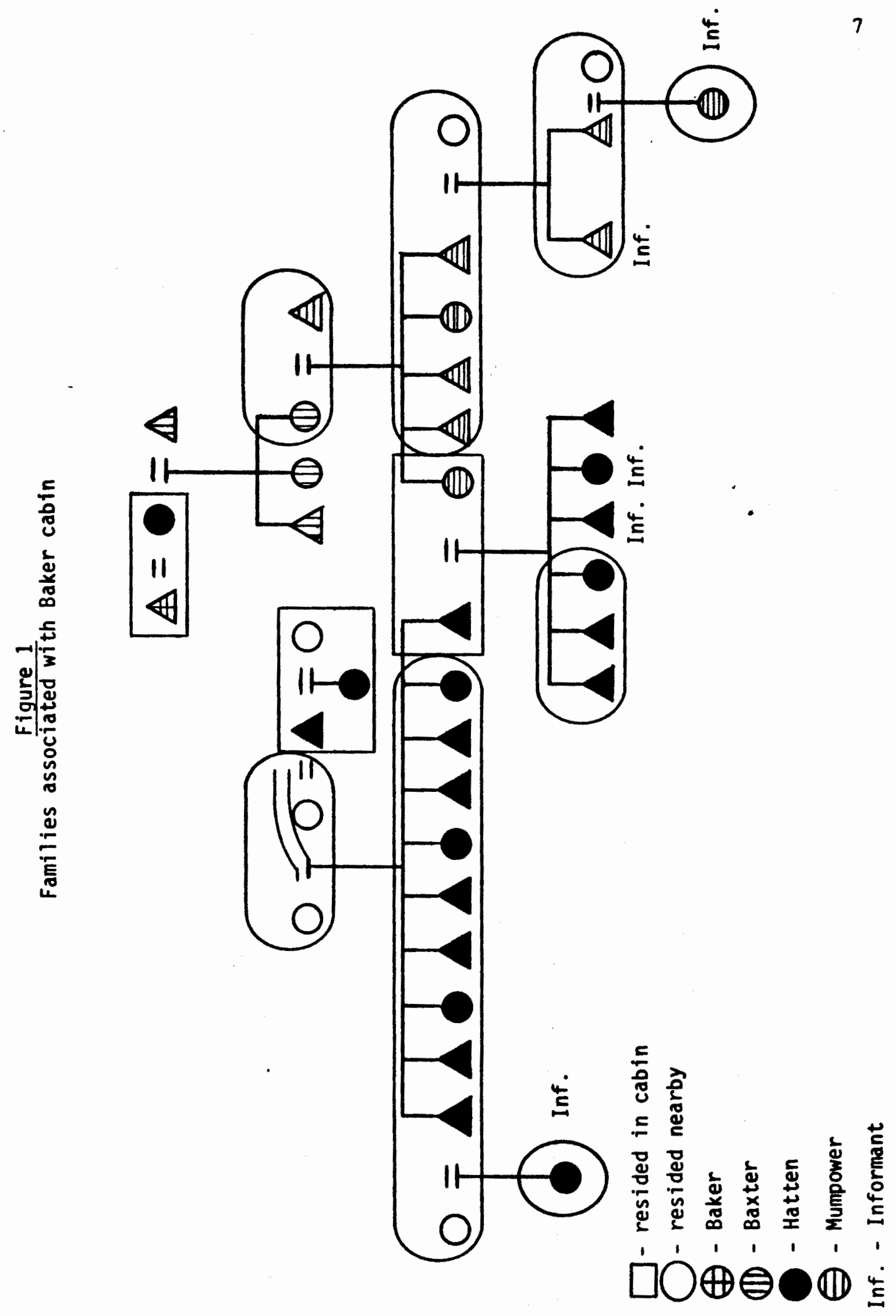


Baken left Jackson County, Missouri, in a wagon train which was bound for Oregon (Dart n.d.). After 160 days on the trail they reached Jack Knife (present Eagle Creek), Oregon, on October 10, 1846 (Hattan 1944). Jane Hattan left her three children in Illinois with the expectation of returning for them in two or three years but it was forty years before she saw then again.

The U.S. Govermment provided free land to individuals who were residents of Oregon Territory prior to December 1, 1850. Male residents could clain up to 320 acres and a wife received a donation equal to that of her husband (U.S. Govermment 1953). In September 1847 Horace Baker and Mark Hattan settled claims of 640 acres each even though Baker was legally entitled to only 320 acres since he was not married to Jane Hattan. According to Clara Dart's ledger Mark built a cabin on his land claim in that same year but there is no record of any Baker construction at that time. In 1849 Martha Hattan died after having suffered from "consumption" for some time and Mark returned 320 acres of his land clain to the goverrment (Anonymous 1903:836). In 1853 Mark Hattan lists his daughter Mary Jane as his heir (U.S. Govermment 1953).

The Clackamas County Census of 1849 taken on March 18 lists a household headed by Horace Baker but none for Mark Hattan. The U.S. Census for 1850 taken on June 30 shows Horace Baken age 47 heading a household composed of himself, Jane Baker age 31, Mark Haton age 28, Mary Haton age 2, Seville Iler age 27, Albert Tutteon age 35, and Caroline Fee age 16. This suggests that after the death of his wife Mark Hattan and his daughter moved into the home of Jane Hattan and Horace Baker. Clackanas County Assessment Rolls for 1856 through 1859 indicate that Mark was 
again maintaining a residence on his own donation land claim. According to ane source Mark Hattan married his second wife, Martha Jane Mason, in 1858 (Anonymous 1903:836). If this account is accurate the marriage would have been of very short duration since the Oregon Angus, an Oregon City newspaper, reports that Martha Jane died of bronchitis on February 20, 1858. The 1860 U.S. Census shows that Mark shared a residence with another man John Illves while his daughter, Mary Jane, resided with the Bakers. Mark married his thind wife, Mary Emily Wills, in 1861 and they had ten children (Dart n.d.). He died in 1909 at age 88 survived by Mary Emily and nine children.

\section{THE BAKERS}

Honace Baker married Jane Hattan Baxter on September 19, 1852, (Anonymous 1852) probably because the U.S. Govermment was preparing to survey and register all donation land claims in the territory. However this legal marriage did not prevent questions about the legality of Baker's claim to 640 acres. Documents dated October 2, 1855, show that the government refused to accept Baker's claim since he was not married to Jane prior to December 1, 1850 Marian Charriere personal communication). Clackamas County Assessment Rolls for 1856 show Horace Baker holding 640 acres, however, the assessment rolls for 1857 show only 320 acres. According to the assessment rolls dated October 1858 Baker was again in possession of 640 acres. Thus it would appear that for at least scme period of time Baker lost one half of his land claim probably through government action but managed to regain it eventually.

The 1850 U.S. Census lists Baker as a pumpmaker but in the 1860, 
1870 , and 1880 censuses he is designated a famer. According to one source Baker made wooden pumps and went about the countryside installing them leaving Jane alone frequently (Hattan 1944). In 1851 Baker and two other men petitioned the Oregon Territory Legislative Assembly to obtain a charter for a water works in Oregon City. An act was passed by the legislature in 1854 incorporating the Oregon City Water Company. This company was composed of Baker and four other men, and was charged with providing "a constant supply of fresh and pure water". There are no further details known about this company or its history.

In 1872 Baker built a slack-cable ferry across the Clackamas River, just above the present bridge site. Baker's Ferry, as it was called, was swept away by high water in 1882 and the county built a covered bridge across the river the following year (Marian Charriere personal communication). Baker also operated a rock quarry on his land claim and his quarry provided some of the material used to construct the Oregon City Locks in 1872 (Hattan 1944). The Bakers donated to the govermment "a tract of land situated on the south side of the Clackamas River, from the 'Big Rock' down to Clear Creek and back to 'the hill', for the purpose of propagating salmon" (Marian Charriere personal communication). The hatchery was established in 1876 by Livingstone Stone.

Horace Baker died in 1882 leaving no will to provide for the disposition of his property. Jane Baker petitioned to be appointed administrator of his estate and stated that Horace had three children living in Ohio and one son, L. L. Baker, living in Corvallis, Oregon Marian (Charriere personal cormunication). L. L. Baker also petitioned to be administrator and it is not certain who actually did administer the 
estate. Jane apparently later paid certain suns of money to Horace's four children in exchange for their portion of the estate (Elton Hattan personal conmunication).

Aside from certain public documents there is actually very little known about Horace Baker. No one knows how and when he left his birthplace in Vermont or when and where he married his first wife, the mother of his four children. There are numerous personal and touching stories concerning Jane Hattan Baker but there are none reganding Honace Baker. My efforts to obtain information from Windsor, Vermont, have proven fruitless, and Horace Baker, the namesake of Baker Cabin, remains essentially an elusive individual.

\section{THE MUMPOWERS}

- Jane Hattan Baker left three children behind in Illimis when she came West and it is uncerrtain who raised them. Carlin, the oldest child, died of smallpox while serving with the Union Army during the Civil War (Marian Charriere personal communication). Mary Lucinda married, was widowed, and married again. Julia Ann married Joseph L. Mumpower in 1857 and had five children: Lorenzo, born in 1840; William, bom in 1860; Joseph, born in 1846; Mary Elizabeth, born in 1869; and Annie born in 1873 (Mumpower n.d.). The Mumpowers remained in Illinois until 1874 when they moved to Nebraska where they lived for eight years (Hattan 1944). In July 1882 Mary Elizabeth, Annie, and their parents arrived in Oregon after a trip by rail to San Francisco and then on to Portland by ship. The three older children joined the family at a later time. In September 1883 Jane Baker deeded 245 acres of her land claim to 
Julia Ann Mumpower. The Mumpowers constructed a hame on this property located approximately one-half mile fram Baker Cabin. It is not known where they lived before construction of this house but it is possible that they lived with Jane. Jane Baker then deeded another one and onehalf acres to Joseph G. Mumpower, her grandson, in 1884. The reason for this gift is uncertain since Joseph did not marry until 1894 (Elton Hattan personal communication). Some time during 1883 Jane retumed to Illinois to visit her daughter Mary Lucinda who apparently never came to Oregon (Marian Charriere personal conmunication).

Mary Elizabeth Mumpower maxnied John Jackson Hattan, one of Mark Hattan's sons, in November of 1894. Their first residence was on the Hattan donation land claim and here their first son, Elton Mumpower, was born in 1895. Apparently a short time later Mary Elizabeth, John, and Eltan moved into the Baker Cabin to be with Jane since she was in poor health (Elton Hattan personal cormunication). In 1897 Jane Baker deeded the remaining 176.36 acres of her land which included the cabin to Mary Elizabeth and John Hattan with the stipulation that "they will care for her the rest of her life". A second son, Clayton, was born to the Hattans in February 1898 and Jane Baker died in December 1898 at age 79 Marian Charriere personal communication).

A post office had been established for the town of Stone (present day (arver) at the fish hatchery and in 1899 this post office was moved to Baker Cabin where Mary Elizabeth Hattan became the postmistress. The year 1901 proved to be a fateful year for the John Hattan's. In June their thind child, Bessie, was born and in July Clayton met with a fatal accident when he fell and hit his head on a wagon wheel. Later in 
the same year the Hattans purchased the house next door to Mary Elizabeth's parents, the J. L. Murmowers, and Baker Cabin stood vacant from that time until 1940. 


\section{CHAPTER III}

\section{ARCHITECTURAL HISTORY OF THE CABIN}

Baker Cabin is a 20 by 30 foot rectangular $\log$ cabin with six windows each measuring 4 by $2 \frac{1}{2}$ feet. Sills rest on a rubble foundation built up on the east side to make the foundation level. Archeological excavations were conducted here and a lange assemblage of artifacts were recovered including bottles reported earlier by Whlke and Woodward (1974). This report indicates a post-1860 date for the construction of the cabin. Additional test excavations uncovered another bottle sherd to be described later that will also have a bearing on the dating.

The cabin has a second floor or loft with a cantilevered balcony on the east gable end reached by an outside stair. Centered in the west end of the cabin is a quarried stone fireplace. The roof is covered with hand-split shingles. Construction is entirely of small first-growth fir trees with each log being a separate tree (Charles Gillman Davis personal comminication). A count of the growth rings on one log indicates that the tree was approximately forty years old when it was cut. The ends of the logs are sawn while the sides are hewn with either an axe or an adze.

The manner of construction is unusual and there are no other cabins known to have been constructed in this manner in the Northwest (Charles Gillman Davis personal cormunication). The logs are placed on the sills in the manner of a well-stacked woodpile in such a way that no 
chinking is needed to fill up spaces between the logs. There are no pegs or nails fastening the logs together. At the comers and ends, the logs are not notched on fastened by pegs in the usual log cabin style. The logs are instead simply laid quoin style in the mannen of stone masonry (Sloan 1962:65). The quoin style of joining is seen in a few barns constructed in Wisconsin by German settlers.

Portions of the interior walls of the cabin are papered with a New York Times newspaper. Careful study of this paper has revealed an 1875 dateline and mention of the crash of the Zenith balloon which occurred on April 15, 1875. Also mentioned is President U.S. Grant's handling of a currency paric in Washington, D. C. Elton Hattan (personal communication) relates that this papering was done by Mary Elizabeth Mumpower and her sister, Annie, while their grandmother, Jane Baker, was absent from the cabin. The Mumpowers did not reach Oregon until 1882, but the old newspapers were available because Jane never threw away magazines or newspapers.

According to Mary Elizabeth Mumpower Hattan (1944) the hewn logs for Baker Cabin were purchased by Horace Baker and he built the cabin in 1856. She states that in the early 1850's a company in California ondered some cut and finished logs from an Oregon sawmill but the order was cancelled and Baker bought them. Californians were indeed importing lumber from Oregon at that time even though northern California was stocked with vingin timber. Gold was discovened in California in 1848 and the development of lumbering in the Siemas was hampered by an inadequate water supply and the difficulty of competing with the mines for Iabor (Trrockonorton 1961:95). 
Lucia (1965:13) writes that Oregonians suddenly found thenselves "sitting on a fortune" and many new sawmills were constructed to supply the needs of the miners in San Francisco and Sacramento. While locally a thousand board feet brought only $\$ 30.00$ Californians were paying up to $\$ 120.00$ by 1850 . This profitable camerce would certainily seem to bear out the account concerming Baker's purchase of the finished logs. Wahlke and woodwand's (1974) paper based on dated bottle sherds, however, seens to indicate that the cabin may not have been on this site. I will later discuss other artifacts uncovered since their paper relating to the reliability of this account and the dating of the cabin.

Baker Cabin was not occupied after 1901 and a picture taken in 1914 (Figure 2) shows the entire dwelling overgrown by vines and weeds. Elton Hattan (personal communication) recalls that in 1913 he completely removed the boards of the second floor of the cabin for use in a wash house at the John Hattan's new hame. By 1937 the fireplace had collapsed, the roof was gone and the two logs closest to the foundation were completely rotted (Donald Hattan personal communication). In this same year the Old Timers' Association of Oregon was founded and the first project they undertook was the reconstruction and maintenance of Baker Cabin. Mary Elizabeth and John Hattan sold the cabin and an adjoining one and one-half acres of land to the 01d Timers' Association for $\$ 200.00$ in December of 1937 and William E. Mumpower was appointed superintendent of the reconstruction (Anonymous 1937-1972:2). In early 1938 Mumpower reported that the reconstruction was going slowly because few volunteers reported for work. The 0ld Timers' Association decided to initiate "Barm Raising" days during the summer in the hope that more volunteers would 


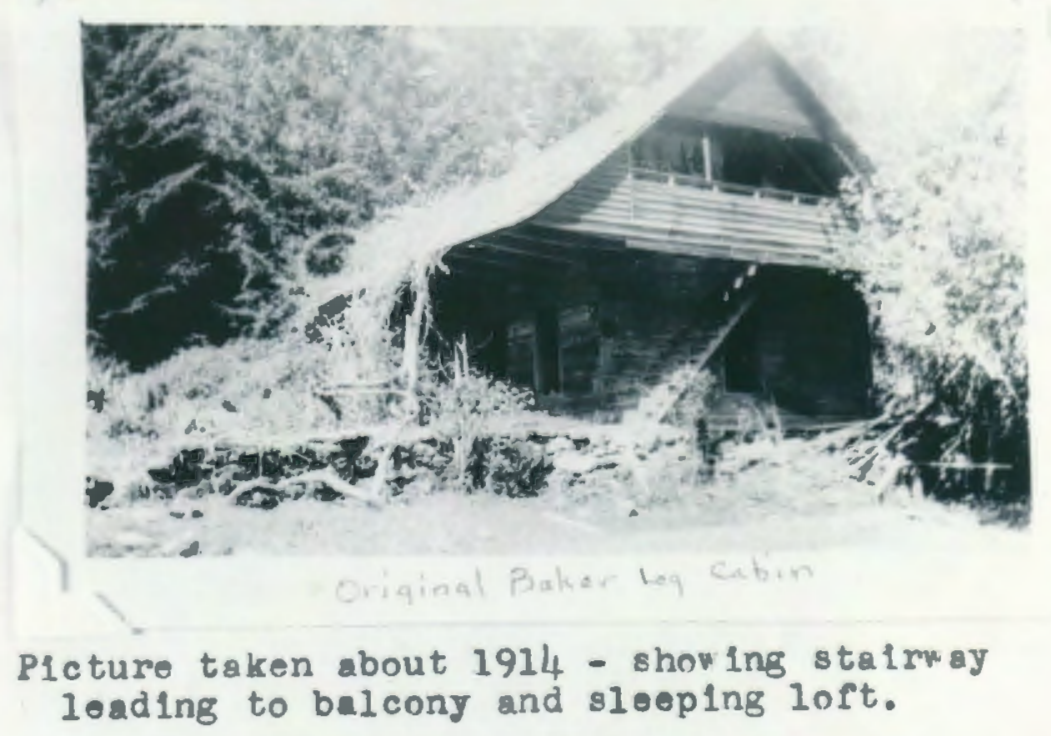

Figure 2. Baker Cabin in circa 1914 
appear (Anonymous 1937-1972:5). During the summers of 1938 and 1939 the cabin was reconstructed and it is possible that some of the labor was provided by the W.P.A. Donald Hattan (personal communication) took part in the work on the cabin and hinself hewed out some of the replacement logs. He recalls that the foundation was in good condition and needed only minor repairs.

On July 16, 1939, with reconstruction campleted the Old Timers' Association met to dedicate the Horace Baker Log Cabin (Anonymous 19371972:22). In 1940 the cabin was wired for electricity and a caretaker took up residence to prevent vandalism. The Old Timers' Association purchased a small strip of land to the east of the cabin from the Southem Pacific Railway in 1941 in onder to enlange the cabin grounds. During World War II the Old Timers' Association was inactive but after the war the grounds were improved and a caretaker's house was constructed near the cabin (Anonymous 1937-1972:47-49).

Archeological excavations since the Wahlke and Woodwand paper (1974) carried out near the caretaker's house have uncovered a 10 by 12 foot foundation and adjoining well. This foundation and well are associated with an apparently earlier assemblage than that found in the cabin foundation and the thin layer of trash (sheet trash) surrounding the cabin. The south wall of this foundation was completely excavated as were short sections of the remains of the east and west walls. The comers of the foundation were located but not excavated. The north corner was located by a small test pit in onder to ascertain the dimensions of the foundation.

The north and south walls of the foundation are of partially 
dressed basalt slabs stacked and held together with some mad mortar. The basalt was dressed with chisel and hammer and the interior of the foundation is smoother than the exterior. The west and east walls of the foundation appear to be simply piled cobbles. This is consistent with log cabin construction since the sills would rest on the dressed stones. The height of the foundation is 18 inches which is consistent with that quoted by Wigginton (1972:55) as the height necessary because "there is a prevalent belief that termites will climb no higher than 18 inches".

Adjacent to the southeast comer of the foundation, excavation revealed a well fifteen feet in depth and three feet in interior diameter. The lower six feet of the well was still completely lined with stacked partially dressed basalt slabs identical to those composing the excavated foundation. The upper part of the well was composed of rubble but it had probably once been lined. In August 1974 during excavation water was standing at thirteen feet. There were two silt deposits within the well and the first seems to correspond to a silt layer in the foundation. Judging from the age of the artifacts found within the well, it was abancioned before 1900 and probably before 1860. Lange boulders and miscellaneous trash were dumped into the well after abandonment and there is the possibility of its use as a privy hole (Figure 3 ).

The nature and purpose of the structure which once stood on the excavated foundation is unbnown. Elton Hatton (personal communication) who lived in Baker Cabin from 1897 until 1901 has provided a detailed 
picture of the cabin and its associated structures at that time (Figure 4). Near the northwest comer of the excavated foundation there is a large basalt outcropping over which Elton recalls a stile. A county road ran north and south along the Baker property and a fence was constructed along the road. The stile permitted access to this road and Elton remembers that near the stile were located a smokehouse and an outhouse. While it is possible that the excavated foundation is the smokehouse of 1900 there was no evidence of ash uncovered. The only well which Eltan recalls is the present one located to the south of Baker Cabin (Figure 4).

At the turn of the century Baker Cabin had three rooms on the first floor and an attached frame structure on the west end which served as a kitchen (Figure 5). Elton's father built the kitchen shortly after the Hattans moved in with Jane Baker. A picture taken probably about 1890 shows a different frame structure attached to the west end of the cabin (Figure 7). There is nothing known conceming this structure but it is possible that it was damaged by fire and replaced by the later structure. Excavation of the sheet trash in this area uncovered an unusually large number of unbent square cut nails and spots of oxidized clay. However, there were no identifiable foundation features from this structure (John woodwand personal conmunication). This is not surprising since the areas surrounding the cabin were graded during the 1940's and prior to that the tramping of animals in the mud around the cabin would have mixed and oblitenated any in situ evidence. 

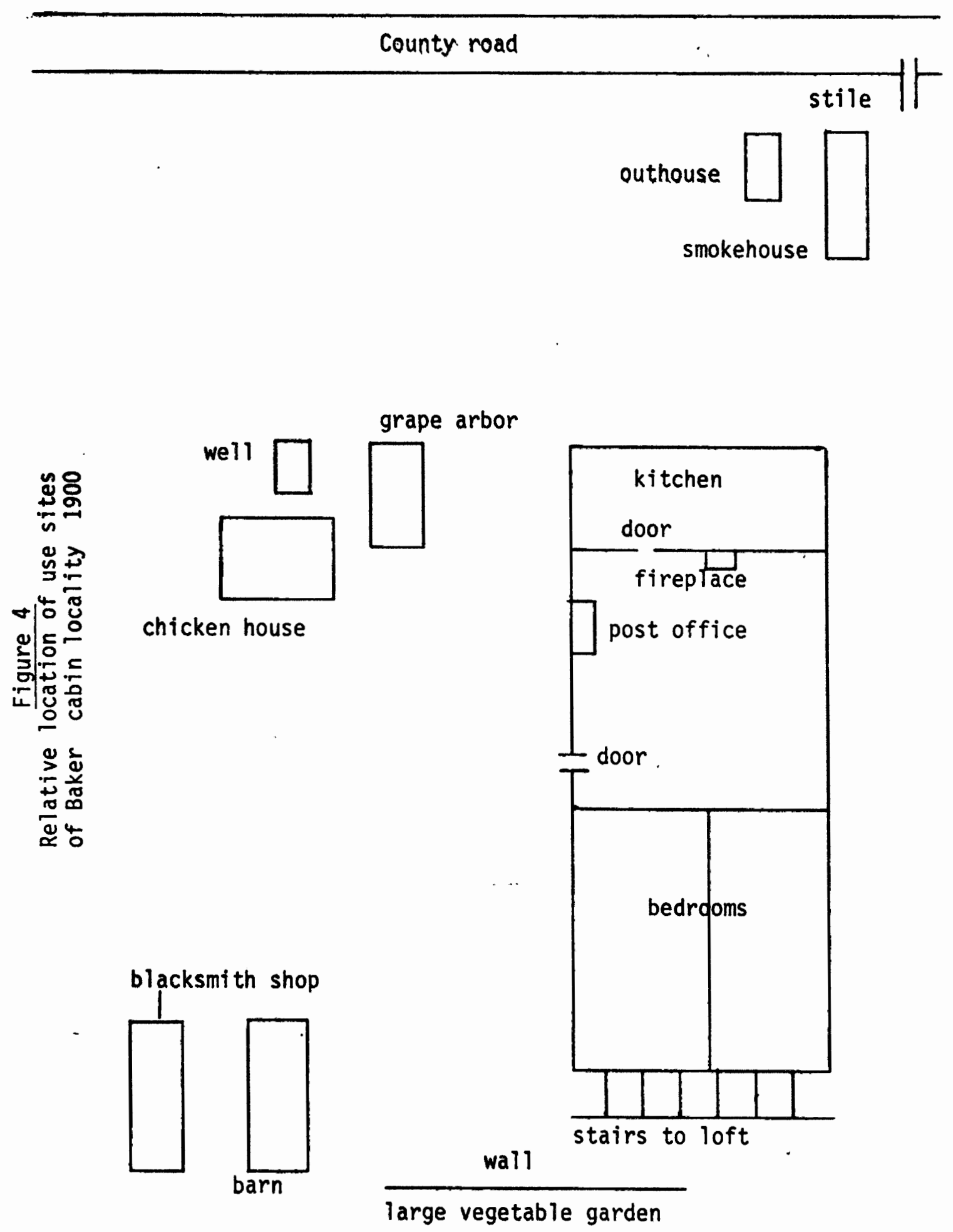


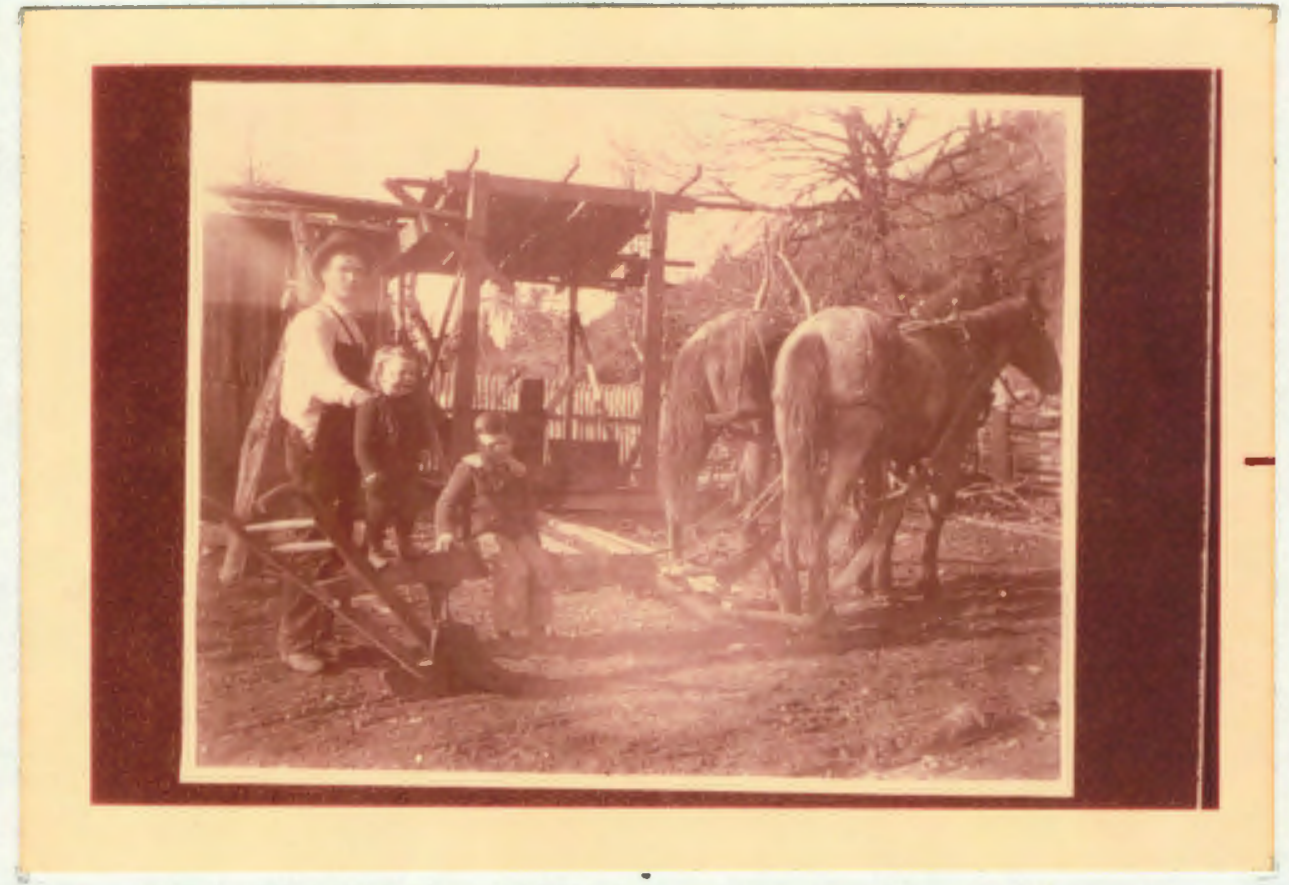

Figrre 5. John, Clayton, and Elton Hattan near the chickenhouse at Baker Cabin circa 1900. 


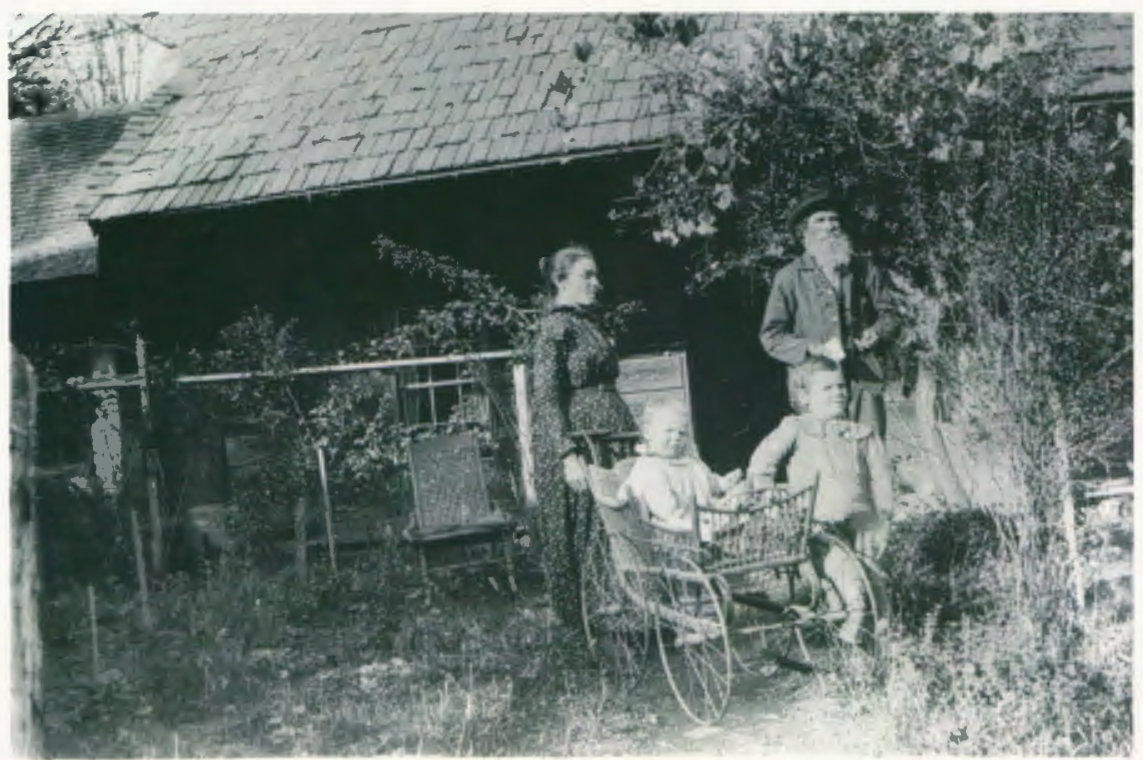

Figure 6. Baker Cabin circa 1900 showing the attached structure on the west end. 


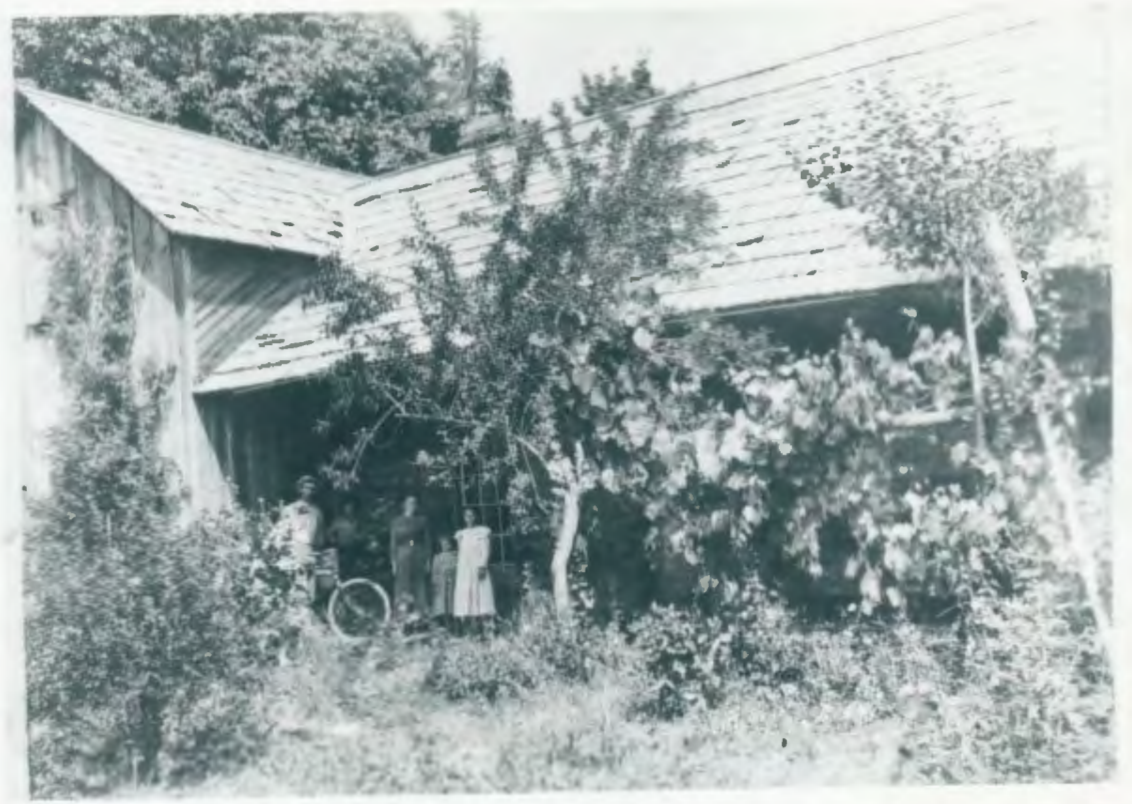

Figure 7. Baker Cabin circa 1890 showing the attached structure on the west end. 
While there is a fairly complete picture of Baker Cabin and its grounds at the turn of the century the picture for earlier periods is unclear. The excavated foundation and adjoining well appear to date from a time previous to Baker Cabin on the basis of associated artifacts. Traditional accounts (Hatton 1944) state that Baker Cabin was constructed in 1856 and this would mean that the excavated foundation was constructed prior to that date. An 1855 survey map contracted by Clackamas County, however, shows neither a dwelling nor any cleared area on any part of Horace Baker's land claim. 
CHAPIER IV

\section{ARTIFACT DESCRIPTION AND DATING}

Several thousand artifacts of glass, ceramic, metal, bone, plastic, and wood were recovered from the excavations of Baker Cabin conducted by Mount Hood Cormunity College field archeology classes. John Woodward made available five categories comprising 643 artifacts which seemed to be most relevant to the purpose of my study. These categories are glass, pottery, buttons, cartridges, and toys, and had not been previously analyzed or described. A small previous analysis of the bottle shends was done by Wahlke and Woodward (1974). It was hoped that these five categories of artifacts would have a bearing on the dating of the cabin.

The following general proveniences were recognized by woodward (personal communication). The provenience sheet trash refers to an assemblage of artifacts recovered from a series of test trenches excavated on all sides of the present cabin. Irenches were excavated along all sides of the foundation and up to 100 feet away from the cabin. Artifacts were found to a depth of one foot below which the soil was sterile. The sheet trash designation was necessary because there was no meaningful cultumal or geological stratignaphy due to disturbance by humans, animals, and weather. In 1948 the Old Timers' Association graded the area around the cabin (Anonymous 1937-1972:43).

The provenience in foundation fill of the present cabin refers to the jumbled rock fill of angular basalt and cobbles used to build up the 
east side of Baker Cabin. The provenience well fill refers to rubble and trash deliberately deposited in the old well. The upper two feet of the well consists of a quantity of rich black clay perhaps resulting from an outhouse placed over the well. Elton Hattan (personal communication) reports an outhouse in that area in 1900.

Within the old foundation there are three units: midden, in silt, and below silt. Midden represents a sheet trash-like accumulation of road fill and trash to a depth of eight inches. In silt refers to two inches of fine water deposited yellow silt which it is assumed was deposited after the structure was abandoned. Below silt consists of lenses of clay, silt, and fallen foundation rock and extends for six inches. This last unit is six inches thick along the north and south walls but thins toward the center of the foundation. The entire site rests on a very compact oxidized surface which represents old terrace conglomenation.

Glass

A total of 361 glass fragments excluding window glass and auto reflector glass were recovered from the Baker Cabin locality. Most of these are fragments of bottles which originally contained medicine, wine, soda pop, or ink. Bottles and jars can be dated by either the mold mark on the base which indicates the glass manufacturer or the mold mark on the body which indicates the firm whose contents were in the bottle. If neither of these marks is present nor identifiable the method of manufacture can sometimes provide an accurate date.

Dateable glass sherds in the Baker Cabin collection will be designated by provenience, color, mold marks, and method of manufacture. Iden- 
tifiable shends recovered in the sheet trash are as follows:

1. 1 clear shend; base mold: "Qि". This mark refers to owens IIlinois Glass Co. and was used from 1929 to 1945 (Toulouse 1971:403).

2. I clear sherd; base mold mark: "O18". This possibly refers to the American Bottle Co. of Chicago and Toledo which was in business from 1905 to 1929 (Toulouse 1971:30). The "18" may refer to the year of manufacture.

3. I clear shoulder sherd; body mold mark: "--broug---". Probably refers to Chesebrough Manufacturing $C_{0}$. of New York which first used bottles for vaseline in 1887 (Wilson 1971:110).

4. I milk glass lid sherd; body mold mark: "Consolida-_.". This sherd matches a fruit jar lid pictured by Berge (1968:201) manufactured by Consolidated Fruit Jar Co. of New York. This mark is dated by Toulouse (1971:123) as 1871 to 1882 .

5. 1 molded black glass bead; multifacited with a tapered hole. Sorensen (1971:37) notes that these beads are popular in sites dating 1830-1850.

6. I green shend; body mold mark: "Coca Cola". This style of bottle was patented in 1923.

7. I aqua sherd; body mold mark: "-mal". This mark is insufficient for identification, however, the base is unscarred which indicates a post-1860 date (Alverson 1967:39).

8. I light aqua sherd; base mold mark: "H". According to Toulouse (1971:231 \& 236) this mark indicates either Holt Glass Works, W. Berkeley, California (1893-1906) or H. J. Heinz and Co. (after 1888).

9. 1 light aqua sherd; no mold marks but has an open pontil so 
pontil 80 probably dates pre-1850 (Alverson 1967:39).

One amber base sherd measuring $23 / 4$ inches square was unearthed in the foundation fill of the present cabin. The base mold mark is " $\mathrm{E} W$ 5" which Toulouse (1971:338) identifies as the mark of Lorenz and Wightman of Pittsburgh. According to Toulouse " $L \& w^{\prime \prime}$ was possibly used from 1851 to 1860 and was definitely used from 1862 to 1871 . This base sherd is unscarred revealing no pontil mark which indicates a post-1860 date (Alverson 1967:39). Consultation with Vito D. Mosso (personal communication) revealed that two bottles in his collection have the "L \& W 5 " base mold mark and match the color and dimensions of this base sherd. These two bottles are identical and have the body mold mark "Dr. J. Hostetter's Stomach Bitters". David Hostetter became a partner of J. H. Redington in 1869 and they began to produce their famous bitters from a recipe belanging to Hostetter's father (Wilson 1971:129). All lines of evidence would seem to point to an 1869 to 1871 date for this sherd.

Identifiable sherds found in the well fill include:

1. 2 yellow green sherds; body mold mark: "--hiedam" and "-ma-n-". On the basis of style and content of the lettering, the cleamess of the glass, and the color this is tentatively identified as "Udolpho Wolfe's Aromatic Schnapps Schiedam" circa 1880 (Wilson 1971:99).

2. 1 light aqua base sherd. There are no marks on this sherd but it has an open pontil so it probably dates pre-1850 (Alverson 1967:39). 3. I light aqua sherd restored from 2 sherds; body mold mark: "Pion--". This sherd conprises the neck and shoulder of a soda pop bottle cormlete with a Hutchinson stopper which was patented in 1879 (Putnam 1965:91). Blumenstein (1965:65) pictures a bottle which matches 
this sherd and which is marked "Pioneer Soda Works P. 0.". Acconding to Polk's City Directories for Portland the Pioneer Soda works was 10cated at 416 Water Street from 1884 until 1910.

4. I black base shend; no mold marks but has an improved pontil so probably dates 1850-1860 (Alverson 1967:39).

In the midden of the old foundation the following fragments were recovered:

1. I clear sherd; base mold mark: "G". This mark refers to Glass Containers, Inc., Los Angeles, and has been used since 1945 (Toulouse 1971:220).

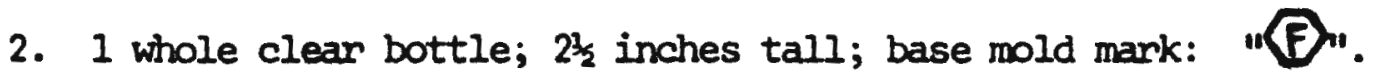
This mark refers to Faimount Glass Wbrks, Inc., Indianapolis, Indiana, and was used from 1945 until 1960 (Toulouse 1971:200-201).

3. 2 clear shends of probable drinking glass. Painted on the glass is a picture of a multi-storied building with the sign "Overland Hotel". Polk's Portland City Directories locate the Overland Hotel at 35 ist N. from 1890 until 1908.

4. I amber shend; no body manks, however, the distinctive log cabin design and the color indicate "Drake's Plantation Bitters" which was patented in 1862 (Watson 1965:99).

Within the silt of the old foundation the following shends were recovered:

1. 59 olive green shends; body mold mark: "P" over "II". The shends include the neck and shoulders of the bottle. Because of color, body manks, and neck this bottle is tentatively identified as "Udolpho Wolfe's Aromatic Schnapps Schiedam" circa 1860 (Wilson 1971:99). 
2. I clear sherd; base mold mark: "L. G. Co.". This mark refers to the Louisville Kentuaky Glass Works, Louisville, Kentucky, and is circa 1880 (Toulouse 1971:323).

Beneath the silt of the old foundation the inventory of sherds excavated is as follows:

1. 1 olive green champagne bottle restored from 9 sherds; 12 inches tall. This bottle has no marks but it has an iron ball pontil which indicates an 1850's date (Wilson 1971:8).

2. I dark olive green case bottle restored fram 34 sherds; 10 inches tall; body mold mark: "Roberts \& Co., Royal Schiedam, Schnapps, New York". This company has not been identified, however, the bottle has an iron ball pontil which indicates an 1850's date (Wilson 1971:8).

3. 1 aqua ink bottle restored from 7 sherds; $2 \frac{1}{2}$ inches tall. This bottle has no marks but is a so-called "umbrella" ink with an open pontil so probably dates pre-1850 (Alverson 1967:39).

4. 1 clear knob sherd; broken from a lid; no mold marks. This sherd is "cheap" glass so probably was part of a container purchased with condiments inside (Vivian Conklin personal communication) and is undateable.

5. I aqua medicine bottle restored from 12 shends; $3 \frac{2}{2}$ inches tall; body mold mark: "Dr. Kennedy's Scrofula Ointment". According to Wilson (1971:123) Kennedy began bottling medicines in 1848. This bottle has an open pontil indicating a probable pre-1850 date (Alverson 1967:39).

6. I aqua medicine bottle partially restored from 27 sherds; body mold mark: "Scrofula Ointment". Based on size, color, and body mold mark this bottle is identified as "Dr. Kennedy's Scrofula Ointment". The 
open pontil again indicates a pre-1850 date (Alverson 1967:39).

Wahllke and Woodwand (1974) analyzed the total collection of bottle sherds excavated as of March 1974 from the sheet trash and the foundation fill of Baker Cabin and noted that all of the bottles represented dated post-1860. Several fragments of a bottle of "Wamer's Safe Kidney and Liver Cure" were found near the base of the rubble fill (John Woodwand personal communication). This company was not formed until 1878 (Wilson 1971:144).

The present analysis seems to bear out the conclusions of hahlke and Wbodward (1974). In fact, with one exception, all dateable sherds from sheet trash and the foundation fill of Baker Cabin appear to post date 1870. Only within the old foundation and the old well fill are pre-1860 sherds found.

\section{Pottery}

Excavations at the Baker Cabin locality unearthed 203 sherds of historical pottery. Following Fontana (1962:91) this collection has been classified into three main types of pottery: earthenware, stoneware, and porcelain (china). Earthenware is a porous crockery made of a dark paste and can be glazed or unglazed. Porcelain or china is made of a white paste and is nonporous while stoneware is of a tan paste and is generally thicker. In this collection there are 140 sherds of stoneware, 46 of earthenware, and 17 of porcelain.

The dating of historical pottery is accomplished by use of company hallmarks when present or pottery design if this has been reconded. If a pottery sherd has no hallmark or if the design has not been reconded it 
is usually undateable. Dateable sherds in the Baker Cabin inventory will be designated by provenience, type of pottery, and hallmark or pattern. Identifiable shends unearthed in the sheet trash are as follows:

1. 1 sherd restored from 2 shends, ironstone; hallmark: "Porcelaine De Terre, Trade Mark, coat of arms, -.- Edwands, -.- land". This exact mark is shown in Kovel $(1953: 243)$ and is identified as that used by John Edwerds of Fenton, England after 1891.

2. 1 shend restored from 2 sherds, ironstone. The pattern matches that pictured by Kanm (1951:216) and identified as Blue Willow by Copeland of England. This dates post-1870 (Kamm 1951:145).

3. I sherd restored from 4 sherds, ironstone; hallmark: "Harvest USA". The pattern is that of a compote overflowing with grapes in pink on a white background. Neither the hallmark nor the pattern have been positively identified, however, Vivian Conklin (personal conmunication) dates this sherd as post-1900. Woodward (personal communication) recovered a lange sherd of this exact type from Richmond, Oregon, a ghost town which dates between 1900 and 1920 .

In the foundation fill of the present cabin 45 sherds of brown glazed Chinese earthenware were recovered. These sherds appear to be the remains of at least two vessels. Chinese utility earthenware is quite common on historical sites and generally contained rice wine or soy sauce. Bressie (1970:115) dates this ware as 1870 to 1880 .

Identifiable shends found in the well fill include:

1. I rim sherd, ironstone. The pattern is a type known as Spatter Ware which was produced by dipping a fine sponge into paint and dabbing it evenly around the borders. This staffordshire-type of pottery 
is believed to have been manufactured in the United States between 1820 and 1860 (Warman 1972:386).

2. I handle sherd, ironstone. This brown glazed pottery is probably imitation Majolica, made in the United States between 1870 and 1880 (Jennie Welsh personal cormunication).

3. 2 sherds, unrestored; porcelain; hallmark: "-ba". The pattem is an intricate one of small flowers set within reserves formed by foliated scrolls and the style is flow blue. Williams (1973:242) pictures this pattern, named Cuba, and states that it was possibly made by Davenport of England and probably dates circa 1845.

In the midden of the old foundation the following identifiable sherds were unearthed:

1. 1 sherd, ironstone; hallmank: "(", "Homer Laughlin, Hotel". The Homer Laughlin Crina Co. of E. Liverpool, Ohio, was established in 1874 (Thom 1947:133). According to Karm (1951:133) if the name "Homen Laughlin" appears the china dates from 1893 because prior to this time the mark was "Laughlin Bros.".

2. 1 sherd, porcelain. This is the partial base of a cup and has printed in red "made in Japan". This marking dates the sherd as post1891 since in that year the U.S. required all imports to be marked with country of origin (Fontana 1962:93).

Beneath the silt of the old foundation the following sherds were recovered:

1. 1 shend restored from 2 sherds, ironstone; pattern type: Spatterware. As previously noted this probably dates from 1820 to 1860 (Warman 1972:386). 
2. I rim sherd, ironstone. This plate rim has a light blue design and band on the bander and is a Staffordshire-type china circa 1860 (Vivian conklin personal oommunication).

Several clay pipe fragments were also recovered in the sheet trash around Baker Cabin. Two stem fragments and two bowl fragments seem to represent at least three different pipes. One stem fragment is cross hatched and bears the mark "FOr---". This same stem is pictured by Hussey (1957:Plate XITV) and was recovered at Fort Vancouver, Washington. The pictured example bears the complete mark "FORD". According to Lester Ross (personal communication), an archeologist at the Fort Vancouver site, these pipes were produced by J. T. Ford, Manufacturer, Mile End, Stepney, London. Clay pipes were inported by Hudson's Bay Co. from 1824 until 1860 but most probably pre-date 1853 because in that year the U.S. placed a 100 percent tariff on them.

The Baker Cabin pottery collection indicates the same inferences as the glass inventory, Older material, except clay pipes, seens to come from the well fill and the old foundation. Pipes are probably not a good indicator because of reuse.

\section{Buttons}

A total of 41 artifacts classified as buttons were recovered by excavations at Baken Cabin. These will be described by material, size, color, and number of holes. Table I shows the provenience of these specimens.

Metal

size 36 gilt brass with ornate leaf design; 100p shank; shank side 
is marked "Rich Orange". Gilt brass buttons were made between 1800 and 1865, however, prion to 1830 they had no designs or omamentation (Liscomb 1967:78-79). This then dates from 1830 to 1865 . One specimen. size 26 metal pant's button used for fastening suspenders to pants; self shank; late 19th century (Mary Mathilda Fralick personal cormunication). One specimen.

Glass

size 18 black glass with a molded raised pattern around the edge; self shank but may have originally had a metal wire shank for reinforcement. Possibly dates from 1867 or earlier (Albert and Kent 1949:100). Mary Mathilda Fralick (personal communication) who was born in 1884 recalls this same type of button on the basques worn by her mother. One specimen. size 24, black; 4 holes, Post 1840 (Luscomb 1967:80). One specimen.

Shell

Shell buttons are undateable because they have been made for three centuries (Luscomb 1967:180). size 22, white; 2 holes. One specimen. size 24 , white; 2 holes. One specimen. size 30, white; 2 holes. One specimen. Composition

The term "composition" is used by button collectors to refer to any button molded from a mixture of substances and are generally undateable (Luscomb 1967:46). 
size 28 , black with omamented front. Originally had a metal shank wich is missing. One specimen. size 30 , beige with remains of red paint; 2 holes. One specimen. Porcelain

of the seven porcelain buttons recovered six had the rough finished backs indicative of the Prosser Process (Ford 1943:137). This process, patented in 1840, involved the molding of dry powdered clay into iron molds under pressure. Because the clay was compacted there was no shrinkage. This process was used in the manufacture of buttons from 1840 until well into the 20th century. Several buttons of this type have been found at an historical site in Oregon dated 1890-1902 (Wbodwand personal comminication).

size 16, white; 4 holes; Prosser Process, baby clothes button (Mary Mathilda Fralick personal conmunication). One specimen. size 18, white; 4 holes; Prosser Process. One specimen. size 18, Bull's-Eye button with a black body and a white center. so-called because the "pattern resembled the bull's-eye on a target." (Luscomb 1967:28). Originally had a metal shank which is missing. Mostly date from the 1860's (Luscomb 1967:183). One specimen. size 22, pale pink; 2 holes; Prosser Process. One specimen. size 22, salmon pink; 2 holes; Prosser Process. One specimen. size 24, white; 4 holes; Prosser Process. Two specinens.

Casein or Bakelite

The earliest "plastic" was celluloid invented in 1869 and used for the manufacture of eyeglass frames and buttons (Swanson 1965:33). Casein 
was invented in 1900 and langely replaced celluloid in the manufacture of buttons because of its toughness and flexibility. In 1909 Bakelite was patented and is considered to have laid the foundations of the synthetic plastic industry. Bakelite could only be produced in amber color or black. Celluloid is highly flammable and tests revealed that none of the Baker Cabin buttons were of this material. size 18, white; 4 holes; Casein. One specimen. size 20, white; 2 holes; Casein. Six specimens. size 22, white; 2 holes; Casein. Two specimens. size 24, white; 2 holes; Casein. One specimen. size 28 , white; 4 holes; Casein. One specimen. size 30 , white; 4 holes; casein. One specimen. size 20, turquoise blue; 2 holes; Casein. One specimen. size 22, twrquoise blue; 2 holes; Casein. One specimen. size 20, tan; 4 holes; Casein. One specimen. size 22, dark green; 4 holes; Casein. One specimen. size 22, brown; 4 holes; Casein. One specimen. size 24, grey; 4 holes; Casein. One specimen. size 24, dark brown; 4 holes; Bakelite. One specimen. Modern Plastic The term modern plastic refers to polyvinyl which was patented in 1938 and is still used in the manufacture of buttons (Simonds and Chumch 1963:2).

size 18, pearl-white; self shank. One specimen. size 22, pearl-white; 4 holes. Two specimens. size 24 , pearl-white; 4 holes. One specimen. 
size 22, clear; 2 holes. One specimen.

\begin{tabular}{|l|c|c|}
\hline \multicolumn{2}{|c|}{ Provenience of Buttons } \\
\hline & Sheet Trash & $\begin{array}{c}\text { Above Silt of } \\
\text { Old Foundation }\end{array}$ \\
\hline Metal & 2 & \\
\hline Glass & 2 & 1 \\
\hline Porcelain & 6 & 1 \\
\hline Casein or & 12 & 1 \\
\hline Bakelite & 2 & 4 \\
\hline Chell & 2 & \\
\hline Modern Plastic & 1 & \\
\hline
\end{tabular}

As one can see from Table I the langest number of buttons are definitively dated as post-1900. There appear to be only four buttons, those of glass and metal, which definitely date prior to 1900 .

\section{Cartridges}

Excavations of sheet trash around Baker Cabin uncovered 20 identifiable cartridges and shells. Three additional cartridges were recovered from above the silt beds in the excavated foundation. All of the cartridges were identified and dated by individual headstamps placed on the bases by the manufacturers.

The inventory of Baker Cabin cartridges and shells from the sheet 
trash is as follows:

1. Eight . 22 calibre long rifle cartridges with an inpressed "U" on the bases. These were made by the Union Metallic Cartridge Company and "probably date from the 1880's" (Fontana 1962:82).

2. One .22 calibre short rifle cartridge with "U.S." on the base. The United States Cartridge Company of Lowell, Mass., founded in 1868, used this mark (Berge 1968:221).

3. One $\cdot 25-35$ calibre cartridge for the Winchester centerfire rifle with "WRA CO, 25-35 WCF" an the base. This calibre was introduced by the Winchester Repeating Arms Co. in 1895 (Barmes 1965:21).

4. One .22 calibre long rifle cartridge with an impressed " $H$ " on the base. This mark was used for many years by the Winchester Repeating Arms Co. of New Haven, Connecticut, which was founded in 1866 (Horn 1962: 21).

5. One .22 calibre long rifle cartridge with an impressed "O" on the base. This symbol was used by the Hestem Cartridge $C_{0}$. of East Alton, Illinois, founded in 1898 (Hom 1962:14).

6. One 12 gauge shotgun shell with a brass base and a candboand case. The base is inscribed "Western Field No. 12", a mark used by the Western Cartridge Co., East Alton, Illinois (Horn 1962:37).

7. One 12 gauge shotgun shell with a brass base and a cardboard case. The identifying mark on the base is "Winchester No. 12" indicating manufacture by the Winchester Repeating Arms Co., New Haven, Connecticut (Horn 1962:14).

8. One .22 calibre long rifle cartridge with an impressed " $\mathrm{H}$ " on the base. This mark is that of the Winchester Repeating Arms Co. and 
the cartridge is made of stainless steel indicating relatively recent manufacture.

9. Three .22 calibre Iong rifle cartridges with "S) bases. This symbol was used by the Western Cartridge $C_{0}$. of East Alton, Illinois (Bearse 1966:54) and these are made of stainless steel.

10. Two .22 calibre long rifle cartridges with "fi Sped U" on the bases. This mark was used by the Remington-Union Metallic Cartridge Co. of Bridgeport, Conneticut, which was formed by menger in 1902 (Hom 1962:35).

The inventory of cartridges and shells from above the silt beds of the old foundation is as follows:

1. One 12 gauge shotgun shell with a brass base and a cardboard case. The identifying mank on the base if "WRA Co No. 12 Rival" which was used by the Winchester Repeating Arms $C o$. and dates somewhere between 1866 and 1901 (Berge 1968:221).

2. Two .22 calibre long rifle cartridges with "F" on the bases. This mark was used by both the U.S. Army Frankford Arsenal (Fontana 1962:79) and the Federal Cartridge Co. (Horn 1962:59). In either case the cartridges would have been manufactured after 1870 .

Toys

Several dateable children's toys were recovered from the sheet trash around Baker Cabin. A total of eight marbles were unearthed as follows:

1. Two agates; German made; one measuring $1.60 \mathrm{~cm}$. , the other $1.40 \mathrm{~cm}$. 
2. Six Aloro-type imitation agates; U.S. made; ranging in size from $1.40 \mathrm{~cm}$. to $1.60 \mathrm{~cm}$.

All the marbles are post 1901 because they are machine-made (Wallace 1970:84). Prior to 1901 marbles were hand blown and evidenced this style of manufacture.

Seven small "plastic-like" figures averaging one $\mathrm{mm}$. in height were recovered. Shapes included a turkey, a rabbit, a milk bottle, and a heart. Each had a small circle at the top for attachment and possibly they were intended as charms for a bracelet. Tests revealed that all were of celluloid which was discovered in 1869 and was largely supplanted in 1900 by Casein (Swanson 1965:33).

One wooden alphabet black measuring $4 \mathrm{~mm}$. square was found. Pictures on the sides include a cat, an " $\mathrm{H}$ ", a "4", an "R", and a tractor. The tractor would indicate a post 1900 date for this block. One metal, pop-style, gun with the remains of green paint was also recovered. This gun is $16 \mathrm{~mm}$. in length and the pop-style dates it as post-1920. 


\section{CHAPTER V}

\section{CONCLUSIONS}

Tradition sustained by the Hattan and Munower families dates Baker Cabin's construction during the year 1856. Mary Elizabeth Mumpower Hattan (1944) states positively that the cabin was built in that year and other family members support this contention. Historic Homes of Clackamas County (1947), a booklet produced by the Susannah lee Barlow Chapter of the Daughters of the American Revolution of Clackamas County, presents two pages concerning Baker Cabin and provides an 1856 construction date. The 01d Timers' Association along with the Daughters of The American Revolution erected a commemonative marken on the site in 1949 which also gives 1856 as the construction date.

When the Old Timers' Association reconstructed Baken Cabin in the late 1930's decayed logs and the roof were replaced but only minor repairs were done on the foundation (Donald Hattan personal communication). In 1939 J. G. Mumpower provided a swom statement to the effect that the cabin was faithfully reconstructed "in precisely the same place and on the old rock wall that supported the original pioneer cabin" (Appendix 1). Murpower funther notes that he has lived within one half mile of Baker Cabin since Novenber, 1883.

These several lines of evidence would seem to indicate that Baker Cabin was constructed in 1856 and today stands on its original foundation. Archeological evidence, however, does not bear this out. Artifacts from the sheet trash date overwhelmingly post-1860 and glass and pottery sherds 
from the foundation fill would seen to indicate a date around 1870 . Possibly the chinese ware (1870-1880) and the "Warner's Safe Kidney and Liver Cure" (post 1878) shends sifted down over the years to a final resting place within the rubble fill of the foundation. This possibility does not hold true, however, for the "L \& W 5" sherd which has been identified as "Hostetters Bitters" (1869-1900). This base shend was located squarely between two foundation stones in a hosizontal position as shown in Figure 8 (John Woodward personal conmunication).

Artifacts dating prior to 1860 were predominately recovered from the old foundation and the well fill. This certainly seems to suggest that the locality was occupied prior to 1860 and supports Donation Land Clain documents and census material. However, this does not show that the occupants of the locality actually lived in Baken Cabin.

There are several possible hypotheses which would resolve this seening conflict between archeological evidence and historic tradition:

1. Baker Cabin was constructed in 1856 at a presently undiscovered site on the claim but was moved to its present location about 1870 .

2. Baker Cabin was constructed in 1856 on the precise spot that it now stands but reconstruction by the Old Timens' Association involved a couplete rebuilding of the foundation.

3. Baker Cabin was constructed in 1856 on the present foundation but extensive repairs were done on the foundation in the 1870's. The old foundation represents a smaller cabin occupied from the late 1840's until 1856.

4. The old foundation with its associated well represents the original construction and habitation of the site. The present cabin is 
not the oniginal 1856 cabin referred to in folklore but is rather a cabin constructed about 1870.

The first hypothesis would appear to have no support. Archeological material from the old foundation and well along with Donation Land Claim and census material indicate that the Bakens were living on the site prion to 1850. There would be no reason for a langer structure, the present cabin, to be located elsewhere on the claim. The second hypothesis is seemingly untenable since it contradicts the statements of both J. G. Mumpower and Donald Hattan that the present cabin stands on its original foundation.

The evidence presently available seems to favor either the thind or fourth hypothesis. Perhaps a closer look at the census material would provide support for one or the other. In 1850 the Baker household consisted of six adults and one child while in 1860 there were two adults and three children. The household consisted of three adults by 1870 and in 1880 only Horace and Jane Baker remained. These figures reveal that the household became smaller over the years and would tend to support the thind hypothesis because there would be no need to initiate construction of a larger structure in 1870. However, the cabin, if constructed in 1856, might have been in need of extensive repairs by 1870 .

Actually none of these hypotheses may have validity and another possible explanation can be offered. The Bakers originally resided in a cabin constructed in the late 1840's which is represented by the old foundation and associated well. Donation Land Clain documents show that Baken lost one half of his land claim and assessment records indicate that this loss occurred in 1856 or 1857. The original Baker home was 
located on that portion reclaimed by the U.S. Goverrment and the Bakers were forced to vacate. They moved to the remaining half of their claim and there in 1856 constructed the present Baker Cabin where they remained until 1870. During this period the Bakers regained the other half of their claim and the second cabin site became unsuitable for one reason or another. Finally, around 1870 the present cabin was taken apart, moved, and reassembled on a new foundation located near the first cabin and its adjoining well. Possibly the present well was constructed at this time.

This last hypothesis would to a degree reconcile the archeological evidence and the historic tradition. Baker Cabin would still have been constructed in 1856 but not on its present foundation. However, unless further information becomes available the authentic history of Baker Cabin will never be known. As thme $(1968: 20)$ observes "---archeology is no respector of persons, conventions or traditions" and "it often yields just enough of the truth to make it clear that our preconceived opinion was wrong, but insufficient to provide the full answer". 


\section{BIBLTOGRAPIX}

Adams, W. H.

1974 Archeology of the Recent Past: Silcott, Washington, 19001930. Paper presented to the Northwest Anthropological Conference, Corvallis, Oregon.

Albert, L. S. and Kathryn Kent

1949 The Complete Button Book. Garden City, New York, Doubleday $\&$ Co., Inc.

Alverson, D. J.

1967 Of Bases and Pontil Scars. The Western Collector 5:12:3943.

Anonymous

n.d. A Family Record of Jane Hattan. Document in the poseession of Bessie Hattan Weaver.

Anonymous

1852 Married, in this county. - . Oregon Statesman, Sept. 25, p. 3. Oregon City.

Anonymous

1903 Portrait and Biographical Recond of Portland and Vicinity, Oregon. Chicago, Chapman Publishing $C o$.

Anomymous

1937- Old Timers' Association Minute Book. Ledger in the

1972 possession of Sharon Payne.

Anomymous

1947 Historic Homes of Clackamas County. Susannah Lee Barlow Chapter of the Daughters of the Amerrican Revolution of Clackamas Co., Oregon.

Barnes, F. C.

1965 Cartridges of the World. Chicago, Follett Publishing Co.

Bearse, Ray

1966 Centenfire American Rifle Cartridges 1892-1963. South

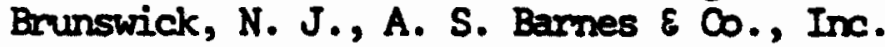

Berge, D. I.

1968 The Gila Bend Stage Station. The Kiva 33:4:169-243. 
Blumenstain, Lym

1965 Redigging the West. Salem, Oregon, Old Time Bottle Publishing $C O$.

Bressie, Wes and Ruby Bressie

1970 Relic Trails to Treasure. Salen, Oregon, Old Time Bottle Publishing Co.

Brown, D. F.

1942 Button Parade. Chicago, Lightner Publishing Corp.

Charriere, Marian Mupower

1974 personal communication.

Clackamas county

1849 Census. Oregon Historical Society Microfilm Collection. Portland.

1856 Assessment Roll. Oregan Historical Society Microfilm Collection. Poxtland.

1856 Census. Oregan Historical Society Microfilm Collection. Portland.

1857 Assessment Roll. Oregon Historical Society Microfilm Collection. Portland.

1858 Assessment Roll. Oregon Historical Society Microfilm Collection. Portland.

1859 Assessment Roll. Oregon Historical Society Microfilm Collection. Portland.

conklin, v. v.

1974 antique dealer and appraiser. personal commication.

Dant, C. H.

n.d. Some Geneologies of the Hattan Family. Ledger in the possession of Isabel Battan MacFarlane.

Davis, C. G.

1974 arahitect AIA. persomal communication.

Fontana, B. L.

1962 Johnny Wand's Ranch: A Study in Historic Archeology. The Kiva $28: 1,2$.

Fond, Grace

1943 The Button Collectors History. Springfield, Mass., PondEkberg $\infty$. 
Fraliok, M. M.

1974 past president, Oregon State Button Club. pereonal coumication.

Preeman, Larry

1964 Grand Old American Bottles. Watkins Glen, N. Y., Century House.

Garth, T. R., Jr.

1947 Early Architecture in the Northwest. The Pacific Northwest Quarterly 38:3:225-240.

Hattan, Danald

1974 personal communication.

Hattan, Elton M.

1974 personal communication.

Hattan, James T. II

1974 personal communication.

Hattan, M. E. M.

1944 Why and How I Came to Oregon. Speech in the possession of Bessie Hattan Weaver.

Horn, W. R.

1962 Headstamps and Cartridge Identification Data. Brlington, Vt., The Horn Company.

Hue, I. N.

1969 Historical Archaeology. New York, Alfred A. Kropf, Inc.

Hussey, J. A.

1957 The History of Fort Vanoouver and Its Physical Structure. Washington State Hlstorical Society.

Kama, M. W.

1951 Old China. Grosse Pointe Farms, Michigan. Privately printed.

Kovel, R. A. and T. H. Kovel

1953 Dictionary of Marks: Pottery and Porcelain. New York, Crown Publishers, Inc.

Lucia, Elis

1965 Head Rig, Story of the West Coast Lumber Industry. Portland, Ore., Overland West Press.

Luscomb, S. C.

1967 The Collector's Encyclopedia of Buttons. New York, Crown Publishers, Inc. 
Lymah, V. M.

1973 Free Land for Free Men. Oregon City, Oregan. Privately printed.

McKearin, G. S. and Helen McKearin

1941 American Glass. New York, Crown Publishers, Inc.

MacFarlane, Isabel Hattan

1974 personal communication.

Mosso, V. D.

1974 past president, Lewis \& Clark Historical Bottle Society. personal communication.

Mmpower, J. A.

n.d. Family Bible with birthdates. In the possession of Veryl Mumpower.

Mumpower, Veryl

1974 personal communication.

Ormsbee, T. H.

1959 English China and its Marks. Great Neck, N. Y., Deenfield Editions, Limited.

Polk, R. L.

1870- Polk's Portland City Directory.

1920

Putram, H. E.

1965 Bottle Identification. Jamestown, Calif. Privately printed.

Ross, Lester

1974 archeologist, Font Vanoouver site. personal cormunication.

Simonds, H. R. and J. M. Church

1963 A Concise Guide to Plastics. New York, Van Nostrand Reinhold.

Sloane, Eric

1962 An Age of Barns. New York, Funk \& Wagnalls, a division of Reader's Digest Books, Inc.

Sorensen, Cloyd

1971 The Enduring Intrigue of Glass Trade Beads. Arizona Highways XIVII:1:20-37.

Staehli, A. M.

1974 architect AIA. personal communication.

Swanson, R. S.

1965 Plastics Technology. Blocmington, Ill., MeKnight \& MeKnight. 
Throckmonton, A. L.

1961 Oregon Argonauts. Portland, Oregon Historical Society.

Thorn, C. J.

1947 Handbook of Old Pottery and Porcelain Marks. New York, Tudor Publishing $C o$.

Toulouse, J. H.

1971 Bottle Makers and Their Marks. Canden, N. J., Thomas Nelson, Inc.

U.S. Goverment

1850 Census. Oregon Historical society Microfilm Collection. Portland.

1860 Census. Oregon Historical Society Microfilm Collection. Portland.

1870 Census. Oregon Historical Society Microfilm Collection. Portland.

1880 Census. Oregon Historical Society Microfilm Collection. Fortland.

1953 Oregon Donation Land Clains Files in the National Archives. Oregon Historical Society Manuscript Collection. Portland.

Van Rensselaer, Stephen

1926 Early American Bottles and Flasks. Petersborough, New Hampshire. Privately printed.

Wahlke, William and Jahn Woodwand

1974 The Bottles from Baker's: The Night Before the Day After. Paper presented to the Northwest Anthropological Conference, Corvalis, Oregon.

Wallace, P. B.

1970 Collecting Antique Marbles. Des Moines, Iowa, Hamestead Book Co.

Varman, E. G.

1972 Eleventh Antiques and Their Current Prices. Union Town, Pa., E. G. Warman Publishing, Inc.

Watson, Richard

1968 Supplement to Bitters Bottles. Canden, N. J., Thamas Nelson $\varepsilon$ Sons.

Watson, Richard

1965 Bitters Bottles. New York, Thomas Nelson \& Sons. 
Heaver, Bessie Hattan

1974 personal comminiation.

Welsh, Jemie

1974 antique dealer and appraiser. personal comminication.

Wigginton, Eliot (editor)

1972 The Foxfire Book. Garden City, N. Y., Anchor Press/Doubleday.

Willians, Petra

1973 Flow Blue China II. Jeffersontown, Ky., Fountain House East.

Wilson, Bill and Betty

1971 19th Century Medicine in Glass. Amador City, Ca., 19th Century fbbby \& Publishing Co.

Ubodvand, J. A.

1974 archeologist, Baker Cabin site. personal comminication. 


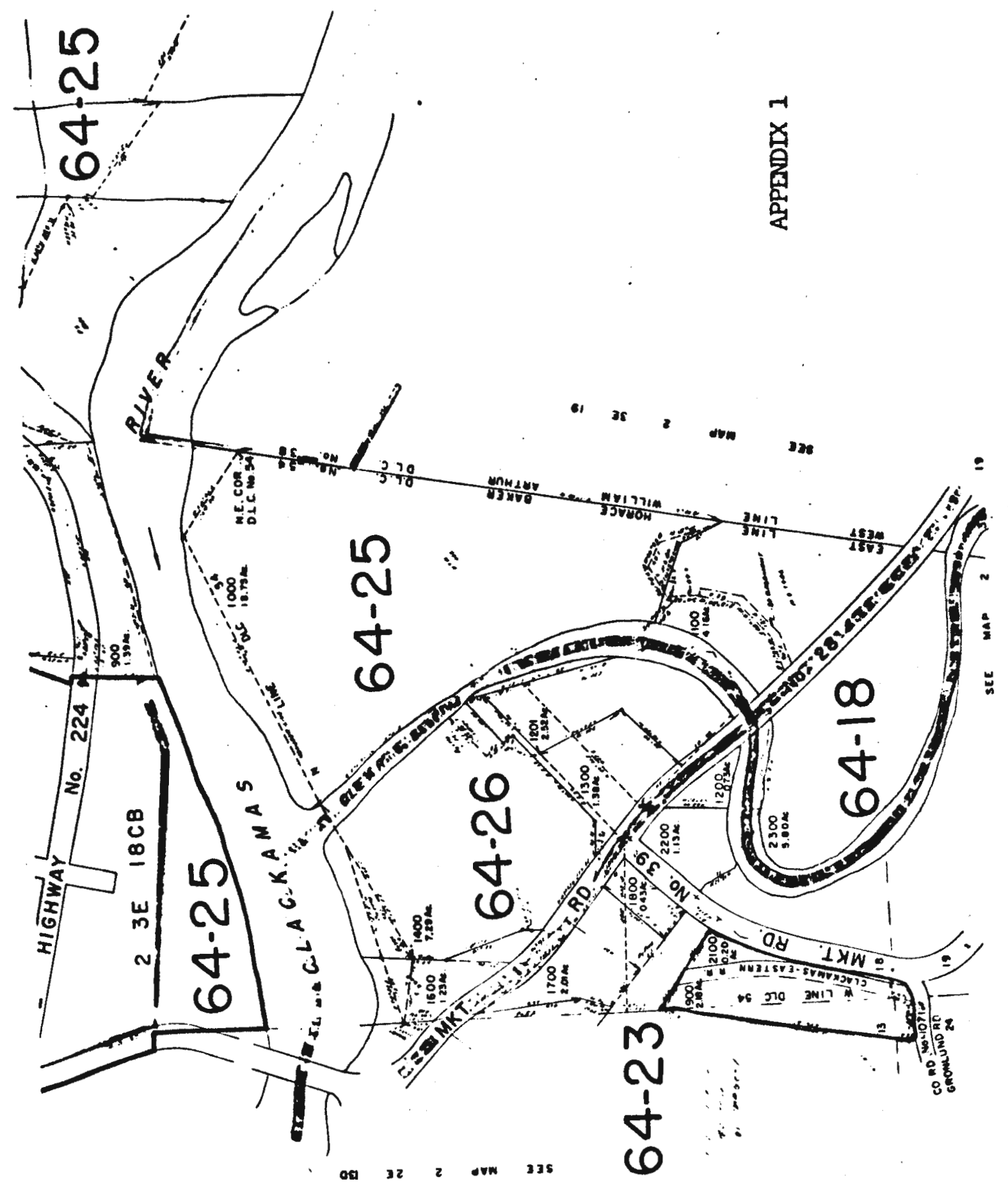




\section{APPENDIX 2}

Carrar, Oregon

Fobruary 8, 1089

I. T. o." "usponer, belns trst duly owarn to terise ond buy tr.at I am a regldent of Jarver, Jregon, that I cume to th1e vicialty "ovember sth, 1883, int have 11 ren within 2038 tran ong-h:1 15 mile or the ploneer logo.bla of lioruoe Buker olnce thist dite. On Jubuury $30 t h$, joso, I wao merried to fincy tinn rkirvin at the o $1 \mathrm{~d}$ loraco lyker cabln. I en funlliar $x 1$ th the const:uot in of the ceibln an? know

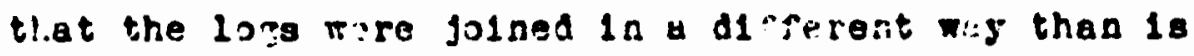
oormoriy used in the conctruetion or 1020 oblns. Flth the oxcention of the botton laxs ant the top loxs wtich rere Dortlsen to other at the cornars, th. Intervening lops mero Lurped together elthout mortlolne. The ritris were pit on top of the u per jalsts so that they rould not sead to spread tho bu!lding. The present purtially reconstructed bulldiag stands In precleplgthe sar.e plice and on the 010 rook wall wileh

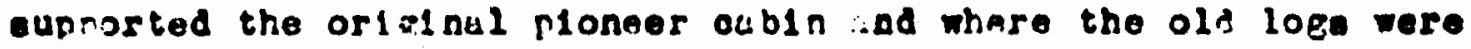
suffiolontly guald trog rave boon used in the reosnstructed bulldinz, only the decaged onse hatla? heen repleced by new loze. 
Th110 21 rinz at the Buker bome, I was told by my ortudmother, Irs." ".juce Juker the the twolve inoh square lare wore orl 31 nu? ly hewn to be shlpred to sin ranclsoo for a bullalas there, but the d yl fel through and Horace baker, ith his ox team hauled the loms to has osbin site und bullt the orlalnal clb1a. These lags belns muoh larnor th, those comsinaly used la log osbin conetruction geve the bulla1ng more at:ullity ad made it legs necessury to mortloe the oornare. Th1s purtiglly reconstruoted csbin w121 be, so far as possiblo when oospletsd, no exact duplloution of the origlnal plonser andin.

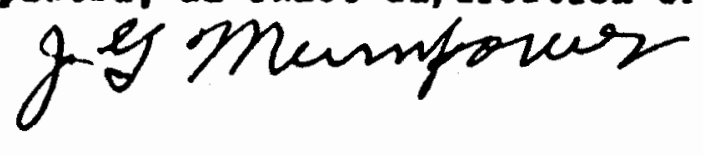

rlaned ant sworn to bofore mo a Yot:ry rubl10

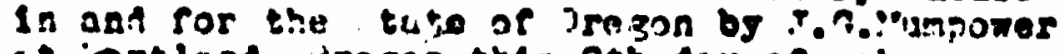
it proland, prgan this sth day of iebruery, 1930. . can s. Fermule of Comedesion expires $10 / 26 / 42$ 


\section{APPENDIX 3}

\section{GLOSSARY}

\section{CANIILEVERED}

projecting beams supported at only ane end.

GABLE

the end wall of a building as distinguished from the front or back wall.

IMPROVED PONTIL an open pantil smoothed to eliminate roughness.

IRON BALL PONTIL

the scar produced by pressing a heated iron ball against an open pontil to remove the protruding glass.

OPEN PONIIL

a jagged circle of protruding glass left when the punty rod was removed.

PONTIL

the scar left on the bases of bottles by the punty rod which was used for the fashioning of hot glass.

SIILS

beams that rest directly on the cabin foundation and on which the floor beans are laid.

STILE

a set of steps for passage over a fence or wall. 